\title{
Flexibility and security policies for elderly workers: a case study in Vietnam
}

\author{
Thi Mai Huong Doan ${ }^{1, *}$, Quynh An $\mathrm{Ngo}^{2}$ \\ ${ }^{1}$ University of Labour and Social Affairs, 43 Tran Duy Hung, Trung Hoa, Cau Giay, Ha Noi, Vietnam \\ ${ }^{2}$ National Economics University, 207 Giai Phong, Hai Ba Trung, Ha Noi, Vietnam
}

\begin{abstract}
National policies in Vietnam show policy shifts towards active ageing and to improving flexibility and security in the labour market. The main question relates to the practice and the introduction of these macro policies at the workplace level is how an employer can combine greater flexibility for the organisation as well as work security for older workers. This paper presents the findings of a survey of wage paid elderly workers and human resource officer in Vietnam (Hanoi, Thaibinh, Ninhbinh) $(n=39$ companies and 428 elderly workers). A flexibility combining security approach for senior workers is most visible in the Vietnam workplaces because of a broader range of facilities such as phased retirement, flexible working hours, education and training, and wage flexible. The survey shows different strategies addressing the issue of older workers. The transport and telecom service sector favour for flexibility in recruitment. The education and health sector are still focused on a 'relief' strategy (adapting workload, tasks and working hours), while the construction industry favour and employability policy. Most of the workplace policies for senior workers show passivity in all items favours flexibility of the organisation, only small rate favour employment security for the workers.
\end{abstract}

\section{Introduction}

This paper presents comparative the employee-level data on senior worker policies in Vietnam. In the background of the Vietnam debate on promoting longer working careers, the main goal of this research is to investigate to what extent companies have used flexible measures that can improve the job and employment security for the elderly employees.

The research questions are:

(a) to what extent do the older workers are employed in the workplace?

(b) how companies combine their benefits (flexibility policies) and the older workers' benefits (security policies) to achieve efficiency when employing elderly workers

(c) are there cross-sectoral variations in the provision and use of flexicurity/securityarrangements for the old aged employees in the companies?

This paper concludes that companies have used more and broader Human resource management policies that provide flexibility for companies and employment security for

\footnotetext{
*Corresponding author: huongdoanthimai@yahoo.com
} 
older workers. This may explain the higher and faster-increasing employment rates among the elderly workers in these areas.

In the following sections, the research method and then the concept of flexicurity are discussed in the context of the active aging debate. The next section describes the institutional contexts and the national policies for older workers in Vietnam. The findings of the survey are presented in the following sections. First, the availability of flexicurity arrangements in the companies and the distribution of the facilities among different sectors of industry are analyzed. Then the next section analyses the degree to which these arrangements are used among older workers in the companies. The conclusions are discussed in the last section.

\section{Method}

The questionnaires were used to explore 39 enterprises chosen from Human resources managers and old workers in Hanoi, Thai Binh, Ninh Binh responded to our survey questions (39 companies and 428 elderly workers). They were interviewed via telephone in 2017. We used the same questionnaire in all three provinces. In each province, the sample is stratified in three sectors of industry and in size categories (50-200 employees), five companies in each industry. The three sectors of the industry that normally use old workers are: (a) construction and mechanical engineering industry; (b) transport and telecommunication services; (c) education and health sector. To identify alternatives to early retirement at the company level we asked the Human resources managers two types of questions: whether the workplaces had a range of different types of practices in terms of recruiting, dismissing and retaining older workers, also arrangements and facilities for workers aged 55+ for women and 60+ for men and how often they were used among these workers.

To identify the elderly workers used effectively at the company level we asked the senior workers some of the questions whether their workplaces had a range of different types of practices in terms of recruiting, dismissing and retaining, and other arrangements, facilities for old workers, and the level that types of these facilities affect their employment and job security (Employment security is about the protection of workers against fluctuations in earned income as a result of job loss (ILO- https://www.ilo.org/global/topics/employmentsecurity/lang--en/index.htm); Job security is the possession of a niche in work, allowing some control over the content of a job, what the worker actually does and the opportunity he or she has of building a career. Another way of presenting job security is to refer to property rights in a persons work. In other words, whereas employment security refers to the sense of attachment to a current enterprise or establishment, job security refers to the sense of attachment to a particular job or range of tasks (ILOhttps://www.ilo.org/sesame/SESHELP.NoteJSI).

Table 1. The survey sample structure.

\begin{tabular}{|c|c|c|c|c|}
\hline & Total & $\begin{array}{c}\text { Education and } \\
\text { Health }\end{array}$ & $\begin{array}{c}\text { Construction and } \\
\text { Mechanical engineering }\end{array}$ & $\begin{array}{c}\text { Transport and } \\
\text { Telecommunication } \\
\text { services }\end{array}$ \\
\hline Hanoi & $\begin{array}{c}169 \\
(15)\end{array}$ & $58(5)$ & $55(5)$ & $56(5)$ \\
\hline Thai Binh & $\begin{array}{c}143 \\
(12)\end{array}$ & $52(4)$ & $46(4)$ & $45(4)$ \\
\hline Ninh Binh & $\begin{array}{c}116 \\
(12)\end{array}$ & $46(4)$ & $33(4)$ & $37(4)$ \\
\hline Total & $\begin{array}{c}428 \\
(39)\end{array}$ & $156(13)$ & $134(13)$ & $138(13)$ \\
\hline
\end{tabular}

Number of elderly employees (number of companies in parentheses) 


\section{Literature review of Flexicurity for older workers}

Flexicurity can be defined as 'a policy strategy that attempts, synchronically and deliberately, to improve the flexibility of labor markets, work organization, and labor relations, and to improve security - employment security and social security - notably for the weaker groups in and outside the labor market' (Wilthagen and Rogowski, 2002: 250). For the older worker, according to the above concept, it is need to combine two approaches. Flexibility is a degree of timely and adequate adjustment in work and wage that changing conditions in order to maintain and enhance firms' competitiveness and productivity. While at the same time providing the elderly employment and allows for enduring and high-quality labor market participation and social inclusion as well as achieve improvement in health (mental, physical), working capacity, income.

With flexibility strategy, employers might have facilities in stable employment relations and in retaining the older employees who are loyal, well-qualified and productive (Auer, 2006). For the elderly employees, they might realize that - to be able to adjust their worklife to more individual preferences - they need more flexible ways of organizing work and employment relations, for example, to balance work and their health, their family life as well (Wilthagen and Tros, 2004; Radushinsky et al., 2018; Radushinsky D. et al. 2019).

In order to get longer working careers, more flexibility is needed in the recruitment, employability, part-time retirement patterns of older employees and so on.

However, the demand for flexibility for elderly workers is a challenge because, the relatively low levels of education and training investments in senior employees, and their difficulties in finding new jobs.

Empirical research has shown the presuppositions that the elderly employees as less adaptable to new technologies (Remery et al., 2003). Besides that, the main barrier to the employability of older workers is the concentration of experiences during the working career in a narrow working field (Thijssen and Van der Velde, 2003).

Following the main ideas underlying the flexicurity concept, we expect that an increase in employment security for the elder worker will have more success when it is combined with more flexibility in an organization's policies.

In the new policy agenda on older workers, the flexicurity concept can promote the willingness of employers to support new facilities for older workers if these increase the flexibility of the labor market and workplaces. The awareness that senior workers make positive contributions in terms of commitment, experience, loyalty and security of human capital might also explain increased attention for policies aimed at retaining and recruiting older workers.

Employers and workers will need to be more ready to accept greater work flexibility as well as employment security for older workers. A possible strategy for the employee is to accept some loss of income security by reducing the benefits for inactive older workers or by postponing the admittance of early retirement but to compensate this by increasing employment security.

Some different types of internal flexibility are usually considered:

(a) flexibility concerns hire and fire;

(b) flexibility refers to working time; jobs and tasks;

(c) flexibility in wages.

These are some combinations of forms of flexibility and security (table 2).

The part-time retirement aids organisational flexibility in working hours, enables a better work-life balance and supports longer working lives (Eurofound, 2007).

The employability of workers can also be increased by job mobility during their career. A well-known barrier to the employability of workers as they get older is that their competences concentrate increasingly on a specialised field of work. Retraining the elderly 
can reduce this barrier. We can expect that programmes for training and education of older workers increase their employability; the functional internal flexibility as well as job or employment security for these workers. A recent empirical study confirms that more training towards the end of the career leads to later labour market exit (Fouarge and Schils, 2007).

Table 2. The combination of flexibility and security approach for elderly workers in workplaces.

\begin{tabular}{|c|c|c|}
\hline Flexibility factors & Job security & Employment security \\
\hline \multicolumn{3}{|c|}{ External arrangement } \\
\hline External arrangement & & $\begin{array}{c}\text { Early retirement } \\
\text { Outplace arrangement } \\
\text { Support self-employment }\end{array}$ \\
\hline \multicolumn{3}{|c|}{ Internal arrangement } \\
\hline Recruitment and dismissal & & $\begin{array}{l}\text { Special recruitment } \\
\text { Part-time retirement; } \\
\text { Part-time contracts }\end{array}$ \\
\hline $\begin{array}{l}\text { Working time, Work } \\
\text { arrangement, Training }\end{array}$ & $\begin{array}{l}\text { Reduced working hours; } \\
\text { Relieve working conditions; } \\
\text { Task rotation; Retraining }\end{array}$ & $\begin{array}{c}\text { Part-time work; } \\
\text { Flexible working hours; } \\
\text { Specific jobs }\end{array}$ \\
\hline Wage flexibility & Flexible pay & Demotion \\
\hline
\end{tabular}

Demotion to a lower-paid job can be a way to retain a senior worker in the labour market, who appears to be too costly, while this also gives options for wage flexibility for the employer.

\section{Results}

\subsection{Work and Retirement in Vietnam}

Vietnam Public policy implies a fundamental shift in policy on older workers. Arrangements for early retirement exit served in many respects by creating external flexibility for the enterprises in redundancy periods and by providing income security for older workers who lost their jobs. But demographic changes and increasing the old worker in the labor market mean that this flexicurity is no longer preferable. New policies have to be more flexible, more preventive and more activating. They are needed to compensate workers for the loss of income security (because of less generous early retirement arrangements, while the period of the contribution of pension insurance is longer, the level of pension benefit decreases) by improving their job and employment security (by external and internal arrangement).

Although the experience has accumulated significantly, elderly workers are physically impaired, so setting the privileges are necessary for longer careers. Article 166 and Article 167 of the 2012 Labor Code (Article 148 and Article 149 of the 2019 Labor Code) stipulate that a number of suitable working regimes must be applied so that elderly workers can continue to work safely and efficiently. The applicable modes include:

(1) Participate in the pension and agreed benefits under the labor contract;

(2) Shorten daily working hours;

(3) Applying a part-time work regime;

(4) Do not perform heavy, hazardous or dangerous work that adversely affects health, except for some special cases under Article 11 of Decree No. 45/2013 / ND-CP:

Experienced and skilled with seniority from 15 years or more of career; be granted a vocational certificate or certificate as an artisan;

Having good health according to professional and jobs standards;

Timely employed; not more than 05 years for each person;

Periodic health examination at least 02 times/year; 
At least 01 person who is not an elderly employee works together;

(5) Received health care at work.

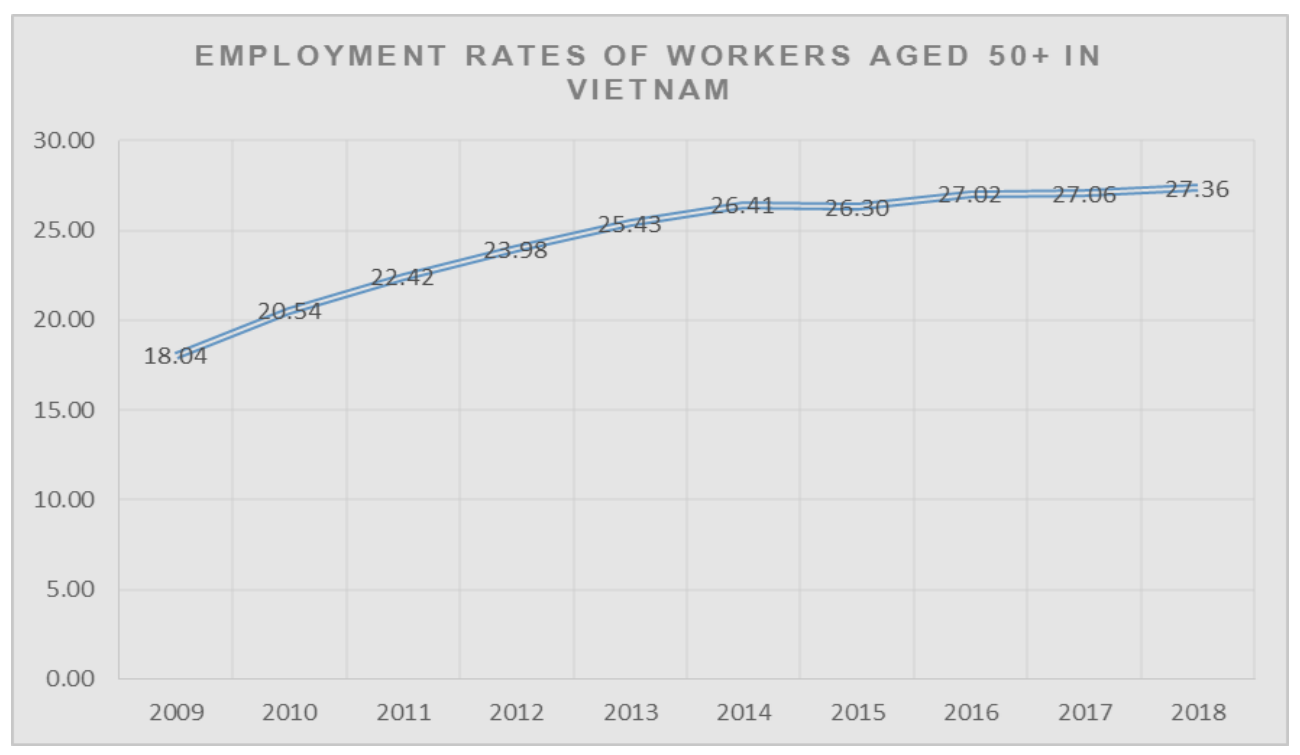

Fig. 1. Employment rate of workers aged $50^{+}$in Vietnam (Source: data from https://www.gso.gov.vn/default.aspx?tabid=714).

Early retirement is popular in Vietnamese last periods. A rate of 86 percent of retirees reports that they retired before reaching their sixtieth birthday, only 33 percent of 2015's workers anticipate doing so. The employment rate of a worker aged 50+ in Vietnam increase by around $10 \%$ in 10 years. The balance of flexibility and security as provided by early labormarket exit arrangements during the last decades of the 20th century is gradually falling away

From 2021, the retirement age shall be increased to the age of 60 years and 3 months old for male employees and 55 years and 04 months for female employees. And then the retirement age shall be increased by 03 months for male employees and 04 months for female employees in the next year. To 2028, the retirement age shall be 62 years old for male employees and 60 years old for female employees.

The social insurance policy also has changed in a way that benefits participants. The social insurance Law 2014 sets the retirement age for women who are 55 and 60 for men. For women with less than 30 years and for a man with less than 35 years of work, the pension is very low. The early retirement with only 20-25 years of work, under the age of 55 for women and 60 for men, taking once packed payment will be a loss. What they paid a year is equal to 2.6 months of salary, when taking once packed payment, a year of work is only calculated 2-month salary. The labor force participation rate for people over 60 years old in 2017 was 46\%, up from 45\% in 2012. (Institute of Labor Science and Social Affairs - ILSSA, 2018).

In Vietnam, up to $60 \%$ of the elderly aged 60-69 are working. But the working rate for the $70-79$ and $80+$ age group decreases very quickly (only $30 \%$ and $11 \%$, respectively). The employment rate of older man workers (45.3\%) is higher than of women $(34.9 \%)$. Thus, each year about 48,000 people out of 120,000 retired workers will continue to work. Figure 1 and Table 3 show that the elderly rate who has employment is gradually increasing over time. 
Table 3. Labor force by age group, 2012-2017 (Source: Institute of Labor Science and Social Affairs (2018), table 2.4, p 14).

\begin{tabular}{|l|c|c|c|c|c|c|}
\hline & 2012 & 2013 & 2014 & 2015 & 2016 & 2017 \\
\hline Number (1000 persons) & 52.348 & 53.246 & 53.748 & 53.984 & 54.445 & 54.524 \\
\hline $15-24$ & 7.888 & 7.886 & 7.585 & 8.012 & 7.511 & 7.496 \\
\hline $25-34$ & 12.727 & 12.714 & 12.879 & 13.227 & 13.307 & 12.990 \\
\hline $35-54$ (female) and 35-59 (male) & 26.233 & 26.632 & 26.931 & 26.230 & 26.849 & 27.409 \\
\hline $55+($ female) and 60+(male) & 5.500 & 6.015 & 6.352 & 6.515 & 6.779 & 6.629 \\
\hline Rate (\%) & 100,00 & 100,00 & 100,00 & 100,00 & 100,00 & 100,00 \\
\hline $15-24$ & 15,07 & 14,81 & 14,11 & 14,84 & 13,79 & 13,75 \\
\hline $25-34$ & 24,31 & 23,88 & 23,96 & 24,50 & 24,44 & 23,82 \\
\hline $35-54$ (female) and 35-59 (male) & 50,11 & 50,02 & 50,11 & 48,59 & 49,31 & 50,27 \\
\hline $55+$ (female) and 60+ (male) & 10,51 & 11,30 & 11,82 & 12,07 & 12,45 & 12,16 \\
\hline
\end{tabular}

\subsection{Employment characteristics of elderly workers}

Based on the analysis of the employment rate of the General Statistics Office (2016) data, the elderly tend to shift from wage paid work to self-employment after retirement. Table 4 shows that $73.5 \%$ of elderly men are self-employed while this rate for women is $68 \%$. However, elderly female workers also account for a large proportion of about $24 \%$ of unpaid household-workers. This is also consistent with the traditional roles and responsibilities in the Vietnamese family after retirement women often take care of their children and support domestic housework.

Table 4. Proportion of elderly workers by employment status, \% (Nguồn: Report of Labor force survey 2015 (GSO, 2016)).

\begin{tabular}{|c|c|c|c|c|}
\hline Age 60+ & Male & Female & Urban & Rural \\
\hline Wage paid & 13.7 & 6.3 & 19.1 & 7.6 \\
\hline $\begin{array}{c}\text { Household labor (Doing domestic works } \\
\text { for own) }\end{array}$ & 9.8 & 24 & 13.9 & 17.7 \\
\hline Self-employment & 73.5 & 68 & 60.5 & 73.5 \\
\hline Employer & 3 & 1.7 & 6.5 & 1.2 \\
\hline
\end{tabular}

The second characteristic is that the elderly workers are mainly operating in the private and household sectors, the number of participants in the state economic sector accounts for a low rate. The proportion of female workers is significantly lower than that of older men (Table 5). The percentage of employees after the retirement age over 60 in the public sector is much lower due to the mandatory retirement age. However, some state-owned economic sectors, especially in health, or education (to retain highly qualified labor resources) ... are allowed to extend the employment of the elderly, but this group only accounts for small density. Therefore, the elderly working for the private and household sectors still make up the majority. 
Table 5. Proportion of elderly workers employed by sector, 2015, \% (Source: Labor force survey report 2015 (General Statistics Office 2016)).

\begin{tabular}{|c|c|c|c|c|}
\hline Age 60+ & Male & Female & Urban & Rural \\
\hline Non-State & 95 & 99.2 & 93.3 & 98.1 \\
\hline State & 5 & 0.8 & 6.7 & 1.9 \\
\hline
\end{tabular}

In terms of employment structure of the elderly by sector, there are also significant differences by urban and rural areas, the structure of maintaining stability throughout the period of 2009-2014 (Table 6).

Table 6. Structure of the elderly worker employment sector, 2009-2014, \% (Source: Labor force survey report 2009-2014 (General Statistics Office)).

\begin{tabular}{|c|l|c|c|c|c|c|c|}
\hline \multicolumn{2}{|c|}{ Age 60+ } & 2009 & 2010 & 2011 & 2012 & 2013 & 2014 \\
\hline \multirow{3}{*}{ Rural } & Service & 11 & 11 & 11 & 12 & 13 & 12 \\
\cline { 2 - 8 } & $\begin{array}{l}\text { Industry\& } \\
\text { Construction }\end{array}$ & 6 & 6 & 5 & 6 & 6 & 6 \\
\cline { 2 - 8 } & Agriculture & 83 & 83 & 84 & 82 & 81 & 82 \\
\hline \multirow{3}{*}{ Urban } & Service & 56 & 54 & 53 & 54 & 54 & 56 \\
\cline { 2 - 8 } & $\begin{array}{l}\text { Industry\& } \\
\text { Construction }\end{array}$ & 9 & 10 & 10 & 10 & 10 & 9 \\
\cline { 2 - 8 } & Agriculture & 35 & 36 & 37 & 36 & 36 & 35 \\
\hline
\end{tabular}

In rural areas, the majority of older persons work in agriculture and forestry, accounting for $82 \%$ in 2014. Significant differences from the structure of urban areas, with diverse career needs, the elderly can easily find jobs in the service sector, accounting for 56\% in 2014.

In addition, according to Table 7, it can be seen that most elderly workers are in unskill jobs, staff and skill workers, while the proportion of older persons who are leaders and technical professionals accounts for a very small proportion. This shows that using of elderly workers is not really effective.

Table 7. Proportion of elderly workers by occupation, 2015, \% (Source: Labor force survey report 2015 (General Statistics Office, 2016)).

\begin{tabular}{|l|c|c|c|c|}
\hline Age 60+ & Male & Female & Urban & Rural \\
\hline Unskill works & 51.6 & 60.5 & 26.9 & 63.8 \\
\hline Staff and skilled workers & 44.6 & 38.5 & 65.8 & 35.1 \\
\hline $\begin{array}{l}\text { Leading officials, technical } \\
\text { experts }\end{array}$ & 3.8 & 1.1 & 7.3 & 1.1 \\
\hline
\end{tabular}

The explanation for the difference in employment between older men and women is that older women spend more time on housework, taking care of their children and grandchildren or are related to the retirement age difference of up to 5 years between males and females.

The data in Table 8 shows that the average income per month from the working of elderly workers is much lower than that of working age, about $32 \%$ lower among men, $46.9 \%$ among women, $30 \%$ in urban and $36.9 \%$ in rural areas.

Table 8. Average income / month of the elderly employee, 2015, 1000 VND (Source: Labor force survey report 2015 (General Statistics Office, 2016)).

\begin{tabular}{|c|c|c|c|c|}
\hline & Male & Female & Urban & Rural \\
\hline Age 15-59 & 4.687 & 3.128 & 5.380 & 3.250 \\
\hline Age 60+ & 3.189 & 1.660 & 3.768 & 2.056 \\
\hline
\end{tabular}




\subsection{Arrangements for the elderly workers in workplaces}

The survey data show that on average, over $80 \%$ of the sample private firm that uses elderly labor has a specific senior labor policy in their human resource management. The focus of our survey is on specific instruments that can help companies use senior workers effectively, that combine forms of internal flexibility and security. As seen in Table 9, the facilities most available in the firms surveyed are those that create work and wage flexibility (ex. working time flexibility) and can simultaneously support a longer stay in the job (employment security): part-time retirement and reduced working hours with a lower wage level. Many firms defended their strategy to continue the practice of full-time retirement at an earlier age.

Arrangements and facilities creating functional flexibility and improving the employability of older workers are widespread in Vietnam.

\section{- Employment security}

Of the sample companies, that recruited older workers (aged 55+ for women and 60+ for men) within the year 2016, according to the respondents, $38 \%$ of companies apply special recruitment policy for the elderly workers.

The most important reasons for recruiting older workers are for specialized tasks, especially in health and education: they are recruited for their individual competences, experience, and qualifications (25\%). Older worker loyalty and commitment to the workplace are supported too $(20 \%)$; They are asserted that the elderly expertise performs better than younger workers (23\%) and their recruitment cost is lower (13\%). Of the sample companies, those recruit elderly workers within the last year believe that they have a good social network that helps their work more effectively (23\%).

The most important objectives to recruit older workers are to recruit an adequate number of employees (68\% of all respondents), then to make work and working conditions more suited to older workers and to retain older workers (both $24 \%$ ). Making older workers more employable is less important (8\%).

Another important aspect is the criteria used for elderly worker firing. Aiding flexible retirement does not gain much support across the sample ( $8 \%$ of all respondents), such as demotion policy, which means that older workers who are willing to work longer with lowerwage, are demoted. It has clearly not an important objective in Vietnam. This policy mostly used in education organizations. The elderly workers are treated as a special employee group, the sample private companies reply that the primary criteria for the older employee dismissals were their work performance, age, and health condition (73\%).

The creation or reservation of specific workplaces or tasks for older workers appears not so popular (23\%). Some large companies (3\%) say that these facilities have decreased since 2015 because of outsourcing non-core activities such as cleaning, security, restaurants, etc.

An important finding is that arrangements creating external-flexibility for the organization are less available in the sample companies, even if it can be argued that these facilities are increasingly needed when the importance of the internal labor-markets decline. Support for older workers towards jobs with other employers is not a facility used. Support for self-employment of older workers appears even less popular.

- Work arrangement and wage flexibility

The option of changing jobs within the company, the option of adaptation of tasks or task rotation to relieve the workload of older workers is available in $37 \%$ of the workplaces in sample companies. In $24 \%$ of the sample, companies have programs or agreements for the retraining of older workers are available. 
Table 9. The availability of facilities for elderly workers by specific arrangements.

\begin{tabular}{|l|c|c|c|c|c|c|c|c|}
\hline \multicolumn{1}{|c|}{ Factors } & $\begin{array}{c}\text { Construction } \\
\text { and } \\
\text { mechanical } \\
\text { engineering }\end{array}$ & \multicolumn{2}{c|}{$\begin{array}{c}\text { Transport and } \\
\text { telecommunication } \\
\text { services }\end{array}$} & \multicolumn{2}{c|}{$\begin{array}{c}\text { Education } \\
\text { and health } \\
\text { sector }\end{array}$} & \multicolumn{2}{|c|}{ Total } \\
\hline & $\mathrm{n}$ & $\%$ & $\mathrm{n}$ & $\%$ & $\mathrm{n}$ & $\%$ & $\mathrm{n}$ & $\%$ \\
\hline Employment security & & & & & & & & \\
\hline Special recruitment & 1 & 8 & 9 & 66 & 5 & 40 & 15 & 38 \\
\hline Part-time retirement & 0 & 0 & 0 & 0 & 3 & 24 & 3 & 8 \\
\hline Part-time contracts & 3 & 24 & 1 & 8 & 1 & 8 & 5 & 13 \\
\hline Work arrangement flexibility & & & & & & & & \\
\hline $\begin{array}{l}\text { Plans/programmes for } \\
\text { education }\end{array}$ & 1 & 8 & 1 & 8 & 7 & 56 & 9 & 24 \\
\hline $\begin{array}{l}\text { Job rotation/horizontal career } \\
\text { movements }\end{array}$ & 2 & 16 & 2 & 16 & 10 & 80 & 14 & 37 \\
\hline $\begin{array}{l}\text { Specific elderly jobs (Reduced } \\
\text { working hours) }\end{array}$ & 2 & 16 & 6 & 46 & 1 & 8 & 9 & 23 \\
\hline $\begin{array}{l}\text { Adaptation tasks to relieve the } \\
\text { workload }\end{array}$ & 1 & 8 & 2 & 16 & 6 & 48 & 9 & 24 \\
\hline $\begin{array}{l}\text { Specific evaluation method of } \\
\text { performing }\end{array}$ & 1 & 8 & 3 & 24 & 6 & 45 & 11 & 26 \\
\hline Wage flexibility & 1 & 8 & 3 & 24 & 4 & 32 & 8 & 21 \\
\hline Flexible pay & 0 & 0 & 0 & 0 & 3 & 24 & 3 & 8 \\
\hline $\begin{array}{l}\text { Demotion towards less paid } \\
\text { jobs }\end{array}$ & & & & & & & 24 \\
\hline
\end{tabular}

Finally, there is also a low availability of arrangements creating wage flexibility in the sampled companies. Around one-fifth use flexible pay, such as merit rating or profit-sharing, for older workers. The only $8 \%$ has a facility or arrangement for demotion towards lesser paid jobs for older workers. The data show that education and health firms have clearly more facilities than other firms in enabling flexibility and job/employment security for elderly employees.

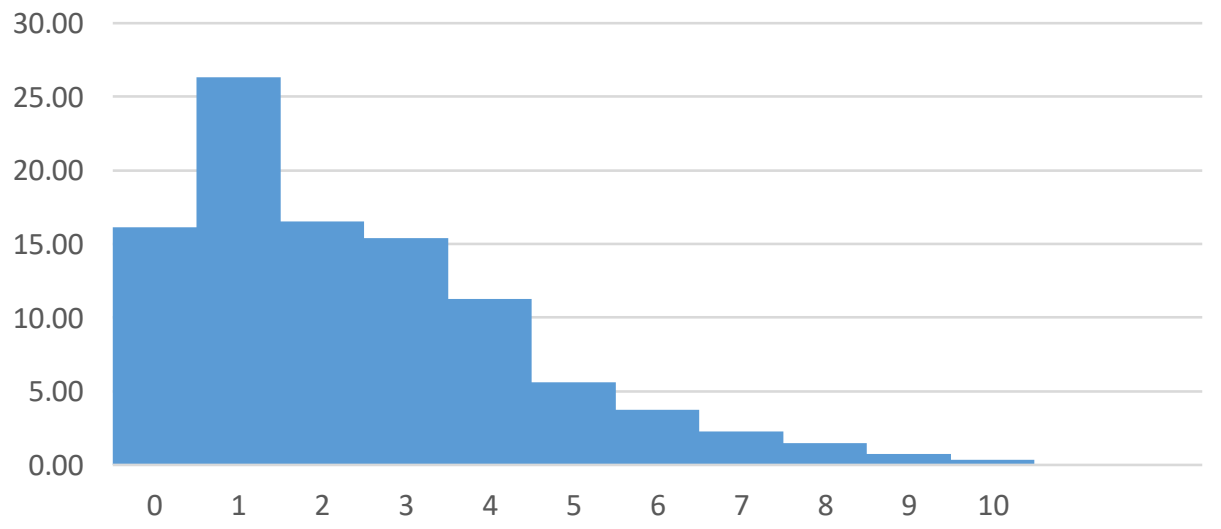

Fig. 2. The distribution of the companies with 0 to 10 flexicurity arrangements. 
The human resource management policies in the construction and mechanical engineering industry seem to be more preventive, and the education and health sector has a more active approach towards older workers than the human resource management policies used in other firms. Figure 2 helps increase understanding of the distribution of the arrangements across companies. Most of the workplaces ( $75 \%$ ) have between 1 and 5 arrangements. Just $16 \%$ have no arrangements at all. Another $14 \%$ have 6 to 10 arrangements.

\subsection{The context of arrangements for elderly workers}

The respondents were aware of creating arrangements and strategies that aid both flexibility and security. When asked to evaluate their human resources strategy and arrangements for older workers, around $35 \%$ of them replied that they should create flexibility and security to the same level. Around $40 \%$ of the respondents fully agree that to create more flexibility among older workers, their income and job security must be restricted. Only $25 \%$ partly agree with this statement.

Further, we asked the respondents which type of security they find most important. In all sectors, 'combination security' scores the highest: $45 \%$ of the human resources managers find in relation to the human resources strategy and arrangements that it is most important that older workers are able to combine work with private life.

The second most important type of security is employment security; that older workers remain active in the labor market, not necessarily in the same job (19\%).

An interesting question is who took the initiative to create these policies and arrangements for elderly workers. Do collective agreements play a more prominent role, or the legislator/government and the employer/human resources department as important actors in the creation of facilities for senior workers. Only more than one-third of the human resources managers think that national legislation is a barrier to the recruitment and the retention of older workers, the rest think that the legislator has driven these facilities. Then some firms perform following the stimulation of legislation.

\subsection{The influence of the organization's policies on the efficiency of the elderly worker's employment (combining the benefits of organization and elderly workers)}

The employment and job security of the elderly employee is influenced by the enterprise arrangements, while controlled by individual factors. The adjusted explanatory coefficient of this model is equal to 0,601 which reflects the independent variables explain $60.1 \%$ for the change of the elderly security. The significance level of the F-test of regression model less than 0.05 reflects the appropriate regression analysis model. The significance level of the test of the regression coefficients of the independent variables is less than 0.05 , that reflects the regression coefficients of the independent variables are statistically significant. The VIF of the independent variables is less than 10 reflecting that the independent variables have multicollinear phenomena but at an acceptable level.

In this regression model, the firm's arrangement is the variable that has the strongest impact on employment security and job security of elderly workers because of the highest regression coefficient $(0.464$, statistical significant level<0.001). The degree of influence of the remaining independent variables on the employment security and job security of elderly workers is, in turn, the coefficient of special recruitment by the enterprise is 0.408 , the coefficient of flexible income is 0.383 ( $\mathrm{p}<0.001)$. 
Table 10. Regression result in elderly employment and work security (Significance levels: ${ }^{*} \mathrm{p}<0.05$ $* * \mathrm{p}<0.01 * * * \mathrm{p}<0.001)$.

\begin{tabular}{|c|c|}
\hline & $\begin{array}{c}\text { Standardized } \\
\text { coefficients }\end{array}$ \\
\hline \multicolumn{2}{|l|}{ Independent Variables } \\
\hline Work arrangement flexibility & $.464 * * *$ \\
\hline Wage flexibility & $.383 * * *$ \\
\hline Special recruitment & $.408 * * *$ \\
\hline \multicolumn{2}{|l|}{ Controls } \\
\hline $\begin{array}{l}\text { Education and Health sector (Ref. Construction and mechanical } \\
\text { engineering) }\end{array}$ & $.167 *$ \\
\hline $\begin{array}{l}\text { Transport and telecommunication services (Ref. Const. and mech. } \\
\text { engineering) }\end{array}$ & $.106^{*}$ \\
\hline Urban/Rural & $.171 * *$ \\
\hline Health condition & $.133^{*}$ \\
\hline Adjusted $\mathrm{R}^{2}$ & 0.601 \\
\hline $\mathrm{F}$ & $32.615 * * *$ \\
\hline Number of observation & 428 \\
\hline
\end{tabular}

In this regression model, the firm's arrangement is the variable that has the strongest impact on employment security and job security of elderly workers because of the highest regression coefficient $(0.464$, statistical significant level $<0.001)$. The degree of influence of the remaining independent variables on the employment security and job security of elderly workers is, in turn, the coefficient of special recruitment by the enterprise is 0.408 , the coefficient of flexible income is 0.383 ( $\mathrm{p}<0.001)$.

\section{Discussion and Conclusion}

In Vietnam, opportunities for early retirement are decreasing, or at least are becoming less attractive and more costly for workers and employers. Therefore, activating forms of flexibility and security are needed in the labor market. This paper has shown that national actors are searching for more activating policies.

Because national policies are limited to just supporting measures to actors at the local area level, it is interesting to examine activities in the workplace.

The survey shows that overall in sample firms in three provinces, those arrangements that provide employment and working internal flexibility are available in more than two-thirds of the sample companies.

Facilities creating employment security are only available in a minority of workplaces. Work flexibility or wage flexibility among older workers even when available, many arrangements for senior workers are seldom used in some places. The survey results reveal large cross-sector differences. Looking at the availability of arrangements, we see that the Health and Education sector companies support longer working careers to a greater extent than other firms. The intensity of use of these arrangements varies also. The data show differences in the forms of flexibility and security that are affected. Health and Education companies follow far more a route towards activation, development, and employability (education, job mobility, recruitment). In Transport and telecommunication services workplaces, there is a 'relief strategy' (reducing working hours and workloads). Construction and mechanical engineering firms appear to be the most passive and lower autonomous in their policies towards senior employees.

These findings on policies for older workers seem to confirm the impression that a flexible multilevel system of the facility such as that in the Health and Education sector is a 
better condition for creating flexicurity strategies than another system in using effectively the elderly workers.

Regression analyses show that as well as the individual and workplace characteristics play a role in the employment and work security of elderly workers, the distribution of flexicurity arrangements has the most important roles. Further analyses are needed to explain why the explanatory power of these characteristics seems to be dependent on the industries.

\section{References}

1. P. Auer, In search of optimal labour market institution: the relationship between stability, flexibility and security in labour markets and beyond', Background paper for keynote speech at CARMA conference 'Flexicurity' (2006)

2. Eurofound Flexibility and security over the life course (Publications Office, Luxembourg, 2007)

3. D. Fouarge, T. Schils, Participation in training and its effect on the decision to retire early. Paper for the Conference of the European Association for Labour Economists (Oslo, 2007)

4. D. Radushinsky, A. Gubankov A. Mottaeva, E3S Web Conf. High-Rise Construction 2017 (HRC 2017) 33, 01042 (2018) DOI: 10.1051/e3sconf/20183301042

5. D. Radushinsky, T.M.H. Doan, V.L. Nguyen, M. Gubankova, et al., E3S Web Conf. (TPACEE 2018) 91, 05026 (2019) DOI: 10.1051/e3sconf/20199105026

6. Ch. Remery, et al., Population Research and Policy Review 22, 21-44 (2003)

7. J. Thijssen, M. van der Velde, Elderly policy from a development perspective. The organization and the older employee (Countinho, Bussum, 2003)

8. Thi Mai Huong Doan, Effective solutions for elderly labour usage, Ministerial level topic (2018)

9. T. Wilthagen, F. Tros, The concept of 'flexicurity': a new approach to regulating employment and labour market. Transfer, 2/2004: conceptual issues and political implementation in Europe, 166-186 (2004)

10. T. Wilthagen, R. Rogowski, Legal Regulation of Transitional Labour Markets The Dynamics of Full Employment: Social Integration through Transitional Labour Markets (Edward Elgar, Cheltenham, 2002)

11. General Statistics Office of Vietnam, Labor force survey report 2009-2015 